\title{
Growth and hematological responses of tambaqui fed different amounts of cassava (Manihot esculenta)
}

\author{
[Crescimento e respostas hematológicas de tambaquis alimentados com diferentes quantidades \\ de mandioca (Manihot esculenta)] \\ P.H.R. Aride ${ }^{1}$, A.T. Oliveira ${ }^{1 *}$, A.M. Oliveira ${ }^{2}$, M.S. Ferreira ${ }^{2}$, R.B. Baptista ${ }^{2}$, \\ S.M. Santos ${ }^{3}$, J. Pantoja-Lima ${ }^{3}$ \\ ${ }^{1}$ Instituto Federal de Educação Ciência e Tecnologia do Amazona - Manaus, AM \\ ${ }^{2}$ Instituto Nacional de Pesquisas da Amazônia - INPA - Petrópolis, AM \\ ${ }^{3}$ Instituto Federal de Educação - Ciência e Tecnologia do Amazonas - Figueiredo, AM
}

\begin{abstract}
Tambaqui,Colossoma macropomum is a fish of primary importance in Brazilian aquaculture and in the Amazon region in particular. The aim of this work is to analyze the combined effects of physical training and levels of dietary cassava (Manihot esculenta) on the hematological parameters, food intake, conversion efficiency, growth ratio and swimming performance of this fish. A diet for tambaqui consisting of $30 \%$ cassava caused decreases in weight gain and specific growth rate compared with the control group. Diets containing $15 \%$ or $45 \%$ cassava did not affect these indices and did not cause hematological changes in tambaqui juveniles, indicating that some amount of cassava can be used as an alternative energy source for this important aquaculture species.
\end{abstract}

Keywords: teleosts, growth, feed evaluation, stress, blood

\section{RESUMO}

Tambaqui Colossoma macropomum, é um peixe de importância fundamental na aquicultura do Brasil e, em particular, na Região Amazônica. O objetivo deste trabalho foi analisar o efeito combinado do treinamento físico com diferentes níveis de macaxeira (Manihot esculenta) na dieta, sobre os parâmetros hematológicos, ingestão alimentar, eficiência de conversão, taxa de crescimento e performance natatória desses peixes. A dieta com 30\% de cassava causou diminuição no ganho de peso e na taxa de crescimento específico quando se comparou ao grupo controle. Dietas contendo $15 \%$ e $45 \%$ de cassava não apresentaram efeito sobre estes índices e não causaram alterações hematológicas significativas em indivíduos juvenis de tambaqui, indicando que estas quantidades de cassava podem ser administradas como alternativa de fonte de energia para essa importante espécie na aquicultura.

Palavras-chave: teleósteos, crescimento, avaliação de alimentos, estresse, sangue

\section{INTRODUCTION}

The greatest obstacle in aquaculture in the Amazon region is the cost and nutritional content of feed. The Amazon region is far from the centers of production, and commercial feed produced in large centers may not supply the nutritional requirements of fish from the Amazon region (Pereira-Filho, 1995). To perform well in a fish farm, fish must receive food that includes the nutrients necessary for their development (Pereira-Filho, 1995; Aride et al., 2006; Aride et al., 2010). Over the past several decades, multiple studies have developed animal feeds using regional products to reduce costs and increase profits. Silva (1997) observed that the incorporation of fruits and seeds from the Amazon region into diets in place of corn meal significantly increased the digestibility of

Recebido em 28 de agosto de 2015

Aceito em 8 de março de 2016

* Autor para correspondência (corresponding author)

E-mail: adriano.oliveira@ifam.edu.br 
proteins, lipids, and carbohydrates and improved the amount of dietary energy available to fish, suggesting that these products are potential feed ingredients for tambaqui.

In the Amazon region, the cassava Manihot esculenta is a major plant source of supplementary food and is a good source of energy, protein, vitamins, minerals, and fiber, all of which maybe important for local fish (PereiraFilho, 1995). One species of teleost fish with commercial importance is the tambaqui, Colossoma macropomum. In its natural environment, this species is omnivorous with a tendency toward frugivory, and its most important habitat, the várzea forest, provides a wide range of fruits. In captivity, tambaqui can ingest both animal and plant proteins and easily adapts to artificial feeding (Aride et al., 2007).

To expand on the existing knowledge of supplementary feeding using regional ingredients, and considering that species-specific knowledge of physiology is very important for fish farming (Baldisserotto, 2002), the present work aims to explore the use of cassava to feed tambaqui. This study evaluates the physiological aspects of tambaqui C. macropomum fed with three different amounts of cassava $M$. esculenta.

\section{MATERIALS AND METHODS}

This study was conducted according to the principles established by the Ethics Committee on Animal Use. The animals used in this study were purchased at Fazenda Santo Antonio (Rio Preto da Eva, Amazonas) and transported to the Ecophysiology and Molecular Evolution laboratory (LEEM) in the National Institute of Amazon Research (INPA). At LEEM, the animals received prophylactic treatment and were acclimated for a period of 15 days, during which they were fed commercial feed containing $36 \%$ crude protein $(\mathrm{CP})$.

The experimental design consisted of three treatment groups and one control group. Each treatment group was fed an experimental diet containing $15 \%, 30 \%$, or $45 \%$ cassava. For each treatment and for the control group, six $60 \mathrm{~L}$ tanks were established with constant aeration and with water renewal every two days. Each tank received eight tambaqui fingerlings weighing $10.59 \pm 2.05 \mathrm{~g}$ (mean $\pm \mathrm{SD}$ ) and measuring 7.14 $\pm 1.57 \mathrm{~cm}$, which were acclimated for two days. At the end of the acclimation period, the fish were fed commercial feed for a week, and they then received test and control rations twice daily (9a.m. and 4p.m.) for 30 days. After 30 days, two fish from each treatment group were randomly collected, subjected to a stress natatorium (swimming tunnel), and then anesthetized with MS222 (5mg/L). Blood sampling was performed by pricking the tail vein with heparinized syringes.

The preparation of test diets consisted of the addition of milled and manually crushed cassava (M. esculenta) byproduct to the commercial diet $(36 \% \mathrm{CP})$ in different proportions $(15 \%, 30 \%$, and $45 \%$ ). The control diet consisted of commercial feed that had been milled and repelletized with $30 \%$ water added. All experimental and control diets were dried in an oven at $55^{\circ} \mathrm{C}$ for 12 hours after repelletization and stored at $-20^{\circ} \mathrm{C}$.

At the beginning and end of the experiment, the animals were measured (standard length) in an appropriate ictiometer accurate to $1 \mathrm{~mm}$ and weighed using a semi-analytical scale with an accuracy of $0.01 \mathrm{~g}$. Growth rates were calculated from measurements of weight and length: Weight gain (WG) and specific growth rate $(\mathrm{G})$ were recorded.

The critical speed of swimming (Ucrit) was determined by exposing the fish to a $10 \mathrm{~cm} / \mathrm{s}$ minimum speed for one hour and gradually increasing the speed every 30 minutes until the fish reached fatigue. The Ucrit value was determined following the recommendations of Brett (1964).

The hematocrit $(\mathrm{Ht})$ was determined by the microhematocrit technique, hemoglobin concentration $([\mathrm{Hb}])$ was determined according to the cyanomethemoglobin method, and the count of circulating red blood cells (RBC) was performed in a Neubauer chamber with an optical microscope. After obtaining these values, the following blood indices were determined: mean corpuscular volume (MCV), mean corpuscular hemoglobin $(\mathrm{MCH})$, and mean corpuscular hemoglobin concentration (MCHC). Glucose concentration was determined using the Accu-Chek Advantage IIelectronic blood glucose 
meter. Plasma concentration and triglycerides were measured using commercial kits (Doles).

After normality tests, treatment groups were compared by one-way ANOVA ( $\mathrm{N}=20$ fish tank ${ }^{-}$ ${ }^{1}$ ), and Tukey's test was used for post hoc comparisons of means at $\mathrm{P}<0.05$.

\section{RESULTS AND DISCUSSION}

Fruits from flooded forests constitute stores of nutrients and energy for tambaqui (Goulding, 1980), representing an important source of carbohydrates (Silva et al., 2003). According to Mori-Pinedo (1999), tambaqui require food that contains primary nutrients for a balanced diet and that provides energy to meet their metabolic needs. In a comparative experiment using different sources of carbohydrates for tilapia, Sena et al., (2012) reported that the addition of cassava to the diet was acceptable to the fish and did not affect growth. These results corroborate those found in the present study, in which only the animals fed diets supplemented with $30 \%$ cassava showed differences $(\mathrm{P}<0.05)$ in specific growth rate and weight gain compared to the control group (Tab. 1). The results obtained in the present study suggest that cassava can be incorporated into tambaqui diets at $15 \%$ or $45 \%$ without affecting their growth. Moreover, the use of $30 \%$ cassava resulted in a slower growth rate than animals fed $15 \%$ or $45 \%$ cassava.

For fish farms in the Amazon region, the use of cassava to feed for tambaqui should adhere to tested proportions (15\% and $45 \%)$ (Tab. 1$)$.

Table 1. Average values ( \pm SEM) of weight, length, and weight gain in C. macropomum fed diets supplemented with different proportions of cassava

\begin{tabular}{lcccc}
\hline \multirow{2}{*}{ Parameters } & \multicolumn{4}{c}{ Cassava (\%) } \\
\cline { 2 - 4 } & Control & $15 \%$ & $30 \%$ & $45 \%$ \\
\hline IW $(\mathrm{g})$ & $17.4 \pm 0.9$ & $21.6 \pm 1.5$ & $24.7 \pm 2.5$ & $24.4 \pm 2.1$ \\
FW $(\mathrm{g})$ & $27.6 \pm 1.6$ & $30.4 \pm 1.5$ & $30.8 \pm 0.9$ & $32.1 \pm 1.6$ \\
IL $(\mathrm{cm})$ & $8.0 \pm 0.2$ & $8.4 \pm 0.2$ & $8.8 \pm 0.3$ & $8.9 \pm 0.3$ \\
FL $(\mathrm{cm})$ & $8.9 \pm 0.3$ & $9.2 \pm 0.1$ & $9.4 \pm 0.2$ & $9.4 \pm 0.2$ \\
G $(\%)$ & $1.54 \pm 0.19$ & $1.14 \pm 0.27$ & $0.78 \pm 0.28^{*}$ & $0.94 \pm 0.17$ \\
WG & $36.7 \pm 3.6$ & $28.3 \pm 5.8$ & $20.0 \pm 6.6^{*}$ & $24.2 \pm 3.9$ \\
\hline
\end{tabular}

SEM, standard error of the mean; IW: initial weight, FW: final weight; IL: Initial length, FL: final length, G: specific growth rate; WG: weight gain; Means with $(*)$ indicate differences between treatments and the control group.

A study by Pereira Junior et al., (2013) showed that cassava flour is very well utilized by tambaqui for weight gain. These results are similar to those obtained by Gallego et al., (1994) for the European eel (Anguilla anguilla). A study by Sena et al., (2012) found that it is possible to replace corn with cassava leaf in Nile tilapia diets (Oreochromis niloticus). These authors reported that cassava flour and leaf has a binding effect, a favorable feature in aquaculture feeds, reducing feed dissolution and thus reducing nutrient loss. The results obtained in this study suggest the viability of decreasing the cost of producing tambaqui in the Amazon region, where diet accounts for over $50 \%$ of production costs.
[Hb], RBC, and Ht are primary hematological indices of the ability to transport oxygen through the blood and of its use by the body (Randall, 1982), and they can be used to indicate the nutritional status of the animal. Barros et al., (2002) studied the addition of small amounts of cotton seed flour to the diet of Atlantic salmon and observed that this by-product did not cause changes in $\mathrm{Ht}$ or $[\mathrm{Hb}]$. Progressive decreases in the amount of hemoglobin and in hematocrit levels were observed by Rinchard et al., (2003) in the same species fed increasing amounts of gossypol, an anti-nutritional component of the cotton seed (Gillani et al., 2005). This finding was confirmed by Colin-Negreti et al., (1996), suggesting that feeding fish large amounts of gossypol increases the fragility of their red blood 
cells. In the present study, a significant increase $(\mathrm{P}<0.05)$ in $[\mathrm{Hb}]$ was observed (Tab. 2) in the $30 \%$ cassava treatment compared to the control group, while Ht levels significantly increased in the $15 \%$ cassava treatment. These results suggest that $15 \%$ or $30 \%$ cassava can cause an increase in metabolic oxygen demand.

Table 2. Average values ( \pm SEM) of hematological parameters of $C$. macropomum fed diets supplemented with different proportions of cassava

\begin{tabular}{llcccc}
\hline \multirow{2}{*}{ Parameters } & & \multicolumn{4}{c}{ Cassava } \\
\cline { 3 - 5 } & & Control & $15 \%$ & $30 \%$ & $45 \%$ \\
\hline \multirow{2}{*}[\mathrm{Hb}]{} & Sedentary & $6.31 \pm 0.28$ & $5.61 \pm 0.49$ & $8.68 \pm 1.11^{*}$ & $7.63 \pm 0.96$ \\
& Exercised & $6.09 \pm 0.20$ & $6.60 \pm 0.41$ & $7.64 \pm 1.26$ & $6.74 \pm 1.29$ \\
$\mathrm{Ht}(\%)$ & Sedentary & $25.5 \pm 1.8$ & $28.5 \pm 0.9 *$ & $28.0 \pm 1.1$ & $28.3 \pm 2.5$ \\
& Exercised & $28.3 \pm 0.5$ & $30.8 \pm 0.5$ & $30.5 \pm 1.2$ & $30.0 \pm 0.8$ \\
$\mathrm{RBC}$ & Sedentary & $2.03 \pm 0.06$ & $2.01 \pm 0.18$ & $2.35 \pm 0.19$ & $2.22 \pm 0.12$ \\
& Exercised & $2.11 \pm 0.10$ & $1.96 \pm 0.59$ & $2.32 \pm 0.21$ & $1.95 \pm 0.14$ \\
$\mathrm{VCM}$ & Sedentary & $126.6 \pm 11.2$ & $145.1 \pm 13.9$ & $121.4 \pm 11.1$ & $127.0 \pm 7.5$ \\
& Exercised & $135.1 \pm 8.7$ & $134.1 \pm 19.9$ & $138.7 \pm 13.2$ & $156.7 \pm 14.0$ \\
$\mathrm{HCM}$ & Sedentary & $31.25 \pm 1.70$ & $27.90 \pm 1.28$ & $36.74 \pm 3.43$ & $34.96 \pm 5.33$ \\
& Exercised & $29.00 \pm 1.24$ & $28.16 \pm 5.04$ & $32.46 \pm 2.40$ & $36.48 \pm 9.57$ \\
$\mathrm{CHCM}$ & Sedentary & $24.95 \pm 1.07$ & $19.84 \pm 2.22$ & $31.51 \pm 5.04$ & $27.56 \pm 3.71$ \\
& Exercised & $21.37 \pm 0.70$ & $21.46 \pm 1.22$ & $24.21 \pm 4.25$ & $22.40 \pm 4.20$ \\
\hline
\end{tabular}

SEM, standard error of the mean; Means with $\left(^{*}\right)$ indicate differences between treatments and the control group.

Organic changes caused by feeding are usually verified by stress agents (Aride et al., 2010). Oliveira (2005), using the critical swimming speed (Ucrit) as a stressor to assess the nutritional status of tambaqui fed with fruits and seeds as supplements, noted that the [Hb] and $\mathrm{RBC}$ increased in animals subjected to swimming stresses. According to Seriani et al., (2011), stressed fish exhibited hematological changes, and this was confirmed by França et al., (2013) and Seriani et al., (2011), who showed that changes in $[\mathrm{Hb}]$ followed the introduction of stressful stimuli. The authors suggest that these changes may result from hemoconcentration or hemodilution, which is caused by osmoregulatory dysfunction. According to Frommel and Clemmesen., (2009), this dysfunction can occur due to an attempt to supply the metabolic demand for oxygen because swimming has a high energy demand and, depending on the species, can even further increase the energy requirements. Thus, the increases in $\mathrm{Ht}$ and $[\mathrm{Hb}]$ observed in this study show that stressors cause changes in the measured indices in tambaqui, and supplementation of diets with $15 \%$ and $30 \%$ cassava did not meet the animals' energy demands. The diet containing $45 \%$ cassava did not result in physiological changes and can therefore be used as an energy source for this species.

We observed a change in the total protein levels in the blood of tambaqui fed diets with $30 \%$ cassava when compared to the control group (Tab. 3). No significant difference in the triglyceride levels was observed. 
Growth and hematological...

Table 3. Average values ( $\pm \mathrm{SEM})$ of plasma metabolites of $C$. macropomum fed diets supplemented with different proportions of cassava

\begin{tabular}{llllll}
\hline \multicolumn{5}{c}{ Proportion of Cassava } \\
\hline Parameters & Control & $15 \%$ & $30 \%$ & $45 \%$ \\
\hline $\begin{array}{l}\text { Total Protein } \\
(\mathrm{g} / \mathrm{dL})\end{array}$ & Sedentary & $2.67 \pm 0.25$ & $2.54 \pm 0.34$ & $2.34 \pm 0.08$ & $2.49 \pm 0.25$ \\
& Exercised & $3.76 \pm 0.08 \mathrm{a}$ & $3.08 \pm 0.24 \mathrm{ab}$ & $2.10 \pm 0.21 \mathrm{~b}$ & $3.48 \pm 0.45 \mathrm{ab}$ \\
$\begin{array}{l}\text { Triglycerides } \\
(\mathrm{mg} / \mathrm{dL})\end{array}$ & Sedentary & $184.2 \pm 25.0$ & $210.0 \pm 15.2$ & $179.5 \pm 20.2$ & $187.1 \pm 29.9$ \\
& Exercised & $281.5 \pm 46.8$ & $308.4 \pm 50.4$ & $232.0 \pm 92.1$ & $196.7 \pm 39.2$ \\
\hline
\end{tabular}

SEM, standard error of the mean; Means with different superscript letters are significantly different $(P<0.05)$.

Carbohydrates are stored in the liver as glycogen, which is degraded into glucose in response to energy demand (Urbinati and Carneiro, 2006). Increased plasma cortisol values are frequently associated with the subsequent elevation of plasma glucose and lactate levels (Aride et al., 2010). Glucose is distributed to the tissues via the blood, and its levels increase when its use for energy production is reduced, when glycogenolysis is stimulated through hormonal induction (Ellis et al., 2012), or in stressful situations (Hochachka and Somero, 1984). Season, diet, and time of last food intake also affect glucose blood levels (Conte, 2004).
Dicentrarchus labrax that received feed containing pea seeds showed increased glucose levels proportional to the increasing levels of dietary pea seeds (Gouveia and Davies, 2004). A similar result was observed by Omeregie (2001) after feeding juvenile Labeo senegalensis diets containing mango seeds. The observed increases in glucose levels are within the normal range for fish and did not affect growth. In the present study, significant increases were only observed in glucose concentration (Fig. 1) and cortisol levels (Fig. 2) after exposure to the swimming tunnel.

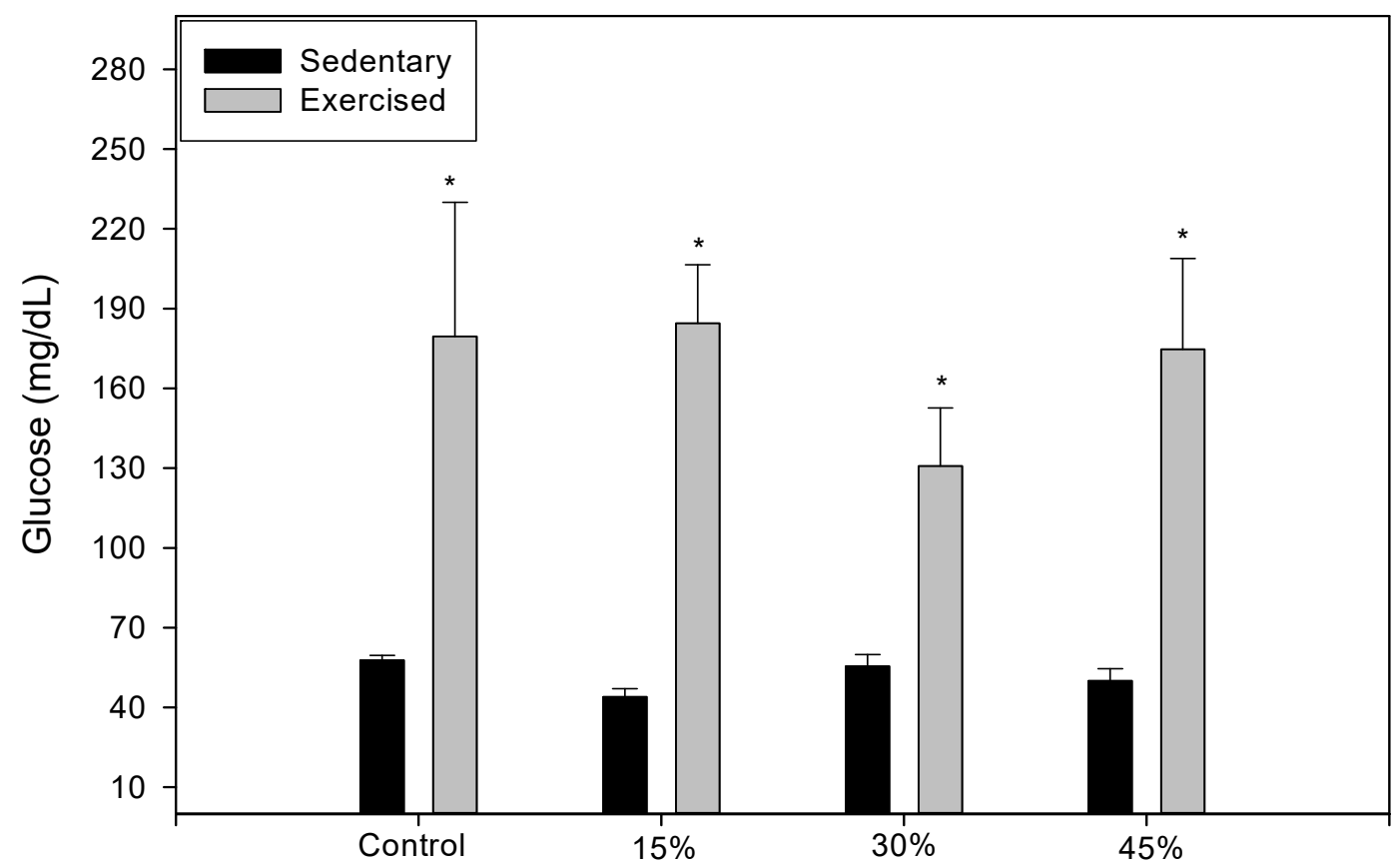

Figure 1. Average values $( \pm \mathrm{SEM})$ of plasma glucose of $C$. macropomum fed diets supplemented with different proportions of cassava. 


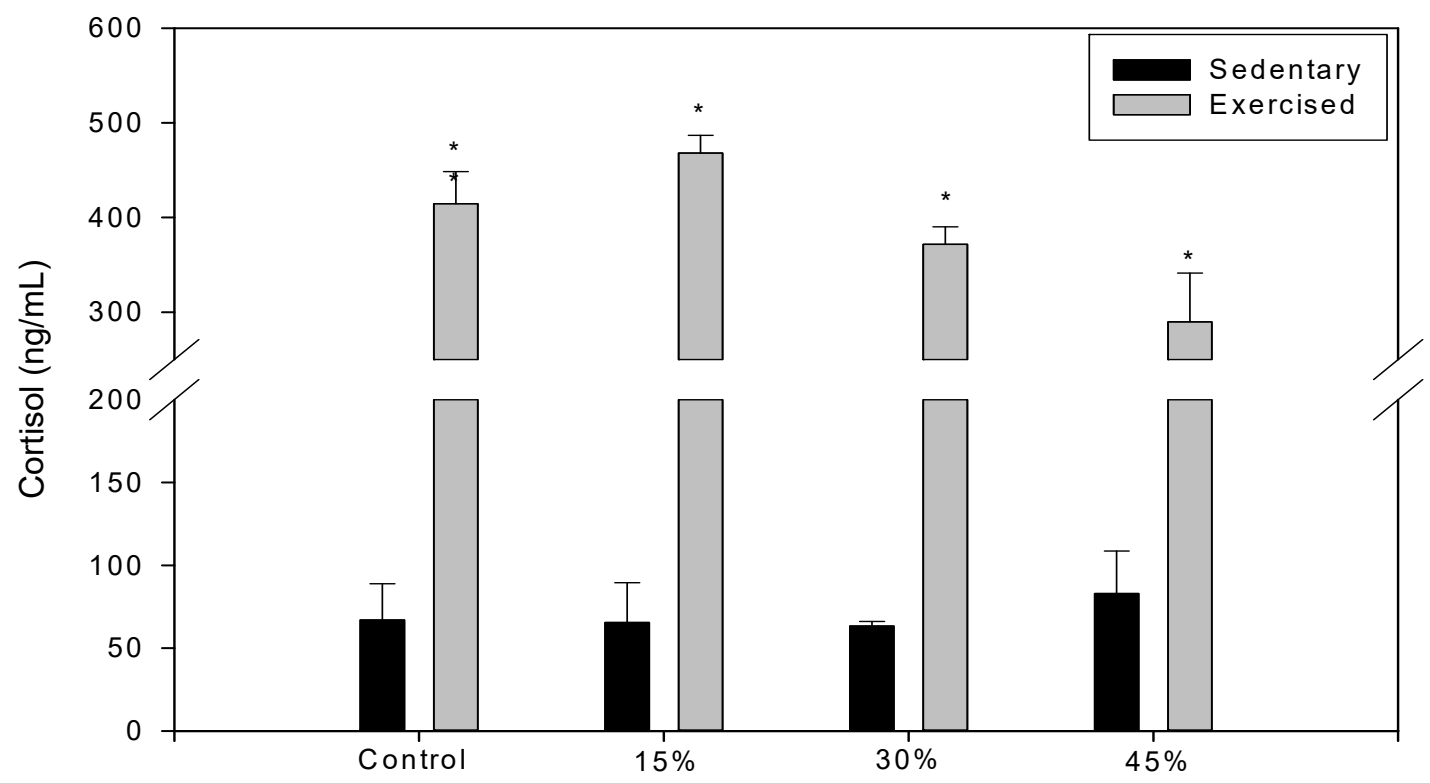

Figure 2. Average values $( \pm \mathrm{SEM})$ of plasma cortisol of $C$. macropomum fed diets supplemented with different proportions of cassava.

The same results were observed for jundiá (Rhamdia quelen) exposed to an acute stressor (Koakoski et al., 2012), reflecting the primary response described by Iwama et al., (2006). Similar results were obtained by Gomes et al., (2003) for tambaqui (C. macropomum) and by Urbinati and Carneiro (2006) for matrinxã (Brycon cephalus). Blood glucose levels are used as a secondary response for measuring stress in fish. Mobilization of glucose occurs to provide the extra energy needed to overcome the imposed stress (Wendelaar Bonga, 1997). Our results show that the hyperglycemia observed in tambaqui after exercise may be maintained by high levels of cortisol originating from glycogenolysis in the liver (Urbinati and Carneiro, 2006).

\section{CONCLUSION}

The results show that the addition of $15 \%$ or $45 \%$ cassava to commercial feed did not affect weight gain or specific growth rate compared to the control group, indicating that this byproduct does not change the growth of tambaqui. Supplementation of commercial feed with $15 \%$ or $45 \%$ cassava did not cause hematological changes in tambaqui. The cassava can be used in tambaqui diets to reduce the costs associated with commercial feed production.

\section{ACKNOWLEDGMENTS}

To CNPQ (Conselho Nacional de Desenvolvimento Científico e Tecnológico) for providing grants (CNPq 557094/2005-4 ALTALI and 554009/2006-4 ÔMEGA); to FAPEAM Foundation for a research fellowship to the last author and providing grants to support this publication (Edital 020/2013-PAPAC); to Program of Post-Graduated in Aquaculture (PPG-Aquacultura-INPA- Nilton Lins) for infrastructure. To the anonymous reviewers, for their truly helpful comments.

\section{REFERENCES}

ARIDE, P.H.R.; FERREIRA, M.S.; DUARTE, R.M. et al. Ascorbic acid (vitamin C) and iron concentration in tambaqui, Colossoma macropomum, iron absorption. J. World Aquacult. Soc., v.41, suppl.2, p.291-297, 2010.

ARIDE, P.H.R.; ROUBACH, R.; NOZAWA, S.R.; VAL, A.L. Tambaqui growth and survival when exposed to different photoperiods. Acta Amazonica, v.36, p.381-384, 2006.

ARIDE, P.H.R.; ROUBACH, R.; VAL, A.L. Tolerance response of tambaqui (CUVIER) to water pH. Aquacult. Res., v.38, p.588-594, 2007. 
BARROS, M.M.; LIM, C.; KLESIUS P.H. Effect of soybean meal replacement by cottonseed meal and iron supplementation on growth, immune response and resistance of channel catfish (Ictalurus puctatus) to Edwardsiella ictaluri challenge. Aquaculture, v.207, p.263-279, 2002.

BALDISSEROTO, B. Fisiologia de peixes aplicada à piscicultura. Santa Maria. 1a Ed. UFSM, 2002.

BRETT, J.R. The respiratory metabolism and swimming performance of young sockeye salmon. J. Fish. Res. Board Can. 21:1183-1226, 1964.

COLIN-NEGRETE, J.; KIESLING, H.E.; ROSS, T.T.; SMITH, J.F. Effect of whole cottonseed on serum constituents, fragility of erythrocyte cells, and reproduction of growing holstein heifers. $J$. Dairy Sci., v.79, p.2016-2023, 1996.

CONTE, F.S. Stress and the welfare of cultured fish. Appl. Anim. Behav. Sci., v.86, p.205-223, 2004.

ELLIS, T.; YILDIZ, H.Y.; LOPEZ-OLMEDA, J. et al. Cortisol and finfish welfare. Fish Physiol. Biochem., v.38, p.163-188, 2012.

FRANÇA, J.G.; RANZANI-PAIVA, M.J.T.; LOMBARDI, J.V. et al. Toxic effect of potassium permanganate on Oreochromus niloticus based on hematological parameters and biomarks of oxidative stress. Int. J. Fish. Aquacult., v.5, p.1-6, 2013.

FROMMEL, A.; CLEMMESEN, C. Use of biochemical indices for analysis of growth in juvenile two-spotted gobies Gobiusculus flavescens of the Baltic sea. Sci. Mar., v.73, suppl.1, p.159-170, 2009.

GALLEGO, G.M; BAZOCO, J.; AKRHARBACH, H. et al. Utilization of different carbohydrates by the european eel (Anguilla anguilla). Aquaculture, v.124, p.99-108, 1994.

GILLANI, G.S.; COCKELL, K.A.; SEPEHR, E. Effects of antinutritional factors on protein digestibility and amino acid availability in foods. J. AOAC Int., v.88, p.967-98, 2005.

GOULDING, M. The fishes and the forest: Explorations in Amazonian Natural History. University of California Press: Berkeley, CA, USA. 280p, 1980.
GOMES， L.C; ARAÚJO-LIMA， C.A.R.M.; ROUBACH, R. et al. Effect of fish density during transportation on stress and mortality of juvenile of tambaqui Colossoma macropomum. J. World Aquacult. Soc., v.34, p.76-84, 2003.

GOUVEIA, A.; DAVIES, S.J. Modulate of the post-prandial glucose profile in juvenile european sea bass Dicentrarchus labrax fed diets varying in starch complexity. J. World Aquacult. Soc., v.35, p.391-400, 2004.

HOCHACHKA, P.W.; SOMERO., G.N. Limiting oxygen availability. In: Biochemical adaptation. HOCHACHKA, P.W.; SOMERO., G.N., New Jersey: University Press Princeton, 1984. p.145-181.

IWAMA, G.K.; AFONSO, L.O.B.; VIJAYAN, M.M. Stress in fish. In: EVANS, D.H.; CLAIBORNE, J.B. (Eds.). The physiology of fishes. 3.ed. Boca Raton: Taylor \& Francis, 2006. p.319-342.

KAOKOSKI, G., OLIVEIRA, T.A., ROSA, J.G.S., FAGUNDES, M., KREUTZ, L.C. and L.J.G. BARCELLOS. Divergent time course of cortisol response to stress in fish of different ages. Physiology and Behaviour, v.106, p.129132, 2012.

MORI-PINEDO, L.A. Determinação das exigências protéico-calóricas de alevinos de Tambaqui (Colossoma macropomun, Cuvier, 1818). 1999. 100f. Tese (Doutorado) - Instituto Nacional de Pesquisa da Amazônia, Universidade do Amazonas, Manaus. AM.

OLIVEIRA, A.M. Aspectos fisiológicos e bioquímicos do tambaqui (Colossoma macropomum, cuvier, 1818) alimentado com dietas suplementadas por frutos e sementes de áreas alagadas. 2005. 73f. Dissertação (Mestrado) - Instituto Nacional de Pesquisas da Amazônia, Universidade Federal do Amazonas, Manaus, AM.

PEREIRA JUNIOR, G.P.; PEREIRA, E.M.O.; PEREIRA FILHO, $M$. et al. Desempenho produtivo de juvenis de tambaqui (Colossoma macropomum, CUVIER 1818) alimentados com rações contendo farinha de crueira de mandioca (Manihot esculenta, CRANTZ) em substituição ao milho (Zea mays). Acta Amazonica, v.43, p.217-226, 2013. 
PEREIRA-FILHO, M. Alternativas para a alimentação de peixes em cativeiro. In: VAL, A.L.; HONCZARYK, A. (Eds.). Criando peixes na Amazônia. Manaus: MCP/INPA, 1995. p.7582.

RANDALL, D. The control of respiration and circulating in fish during exercise and hipoxia. $J$. Exp. Biol., v.100, p.275-288, 1982.

RINCHARD, J.; LEE, K.J.; DABROWSKI, K. et al. Influence of gossypol from dietary cottonseed meal on haematology, reproductive steroids and tissue gossypol enantiomer concentrations in male rainbow trout (Oncorhynchus mykiss). Aquacult. Nutr., v.9, p.275-282, 2003.

SENA, M.F.; AZEVEDO, R.V.; RAMOS A.P.S. et al. Mesquite bean and cassava leaf in diets for Nile tilapia in growth. Acta Sci. Anim. Sci., v.34, p.231-237, 2012.

SERIANI, R.; ABESSA, D.M.S. KIRSCHBAUN, A.A. et al. Relationship between water toxicity and hematological changes in Oreochromis niloticus. Braz. J. Aquatic Sci. Tec., v.15, p.47-53, 2011.
SILVA, J.A.M. Nutrientes, energia e digestibilidade aparente de frutas e sementes consumidos pelo tambaqui (Colossoma macropomum, Cuvier, 1818) nas floretas inundáveis da Amazônia central. 1997. 142f. Tese (Doutorado) - Instituto Nacional de Pesquisas da Amazônia, Universidade do Amazonas, Manaus, AM.

SILVA, J.M., PEREIRA-FIHO, M.; PEREIRA, M.I.O. Valor nutricional e energético de espécies vegetais importantes na alimentação do tambaqui. Acta Amazonica, v.33, p.687-700, 2003.

URBINATI, E.C., CARNEIRO, P.C.F. Sodium chloride added to transport water and physiological responses of matrinxã Brycon amazonicus (Teleost: Characidae). Acta Amazonica, 36, 569-57, 2006.

WENDELAAR BONGA, S.E. The stress response in fish. Physiol. Rev., v.77, p.591-625, 1997. 